\title{
Pengaruh Literasi Keuangan Terhadap Kinerja dan Keberlangsungan UMKM di Kota Denpasar
}

\author{
Ida Ayu Agung Idawati and I Gede Surya Pratama \\ Faculty of Economic and Business, Universitas Warmadewa, Denpasar, Bali-Indonesia \\ idawatiunwar@gmail.com
}

How to cite (in APA style):

Idawati, I, A.A., \& Pratama, I, G, S. (2020). Pengaruh Literasi Keuangan Terhadap Kinerja dan Keberlangsungan UMKM di Kota Denpasar. Warmadewa Management and Business Joural, 2(1) pp.1-9

\begin{abstract}
MSME is a creative industry that tends to have a short-term orientation in making business decisions. Generally SME actors do not have organized information about the financial condition, market share, competition dynamics and track record management. One way to enrich knowledge in managing finances is to use financial literacy. This study aims to analyze the effect of financial literacy on the performance and sustainability of MSMEs in Denpasar City. Data collection using a questionnaire distributed directly to the object of research. The population in the study were three MSME sectors that dominated in Denpasar City, namely the handicraft, culinary and fashion industry sectors totaling 330 MSMEs. The research sample was 100 MSMEs with the method of determining the sample, namely simple random sampling. Structural equation model based on partial least square is used to analyze data. The results showed that there was a significant influence between financial literacy on the performance and sustainability of MSMEs in Denpasar City. The implication of the results of this study is that with a good understanding of financial literacy it is expected that MSME actors will be able to make the right financial and management decisions to improve business performance and sustainability.
\end{abstract}

Keywords: financial literacy, performance, sustainability

\begin{abstract}
Abstrak
UMKM merupakan industri kreatif yang cenderung memiliki orientasi jangka pendek dalam pengambilan keputusan bisnisnya. Umumnya pelaku UMKM tidak memiliki informasi yang terorganisir tentang kondisi keuangan, pangsa pasar, dinamika kompetisi dan jejak rekam manajemen. Salah satu cara yang dapat dilakukan untuk memperkaya pengetahuan dalam mengelola keuangan adalah dengan menggunakan literasi keuangan. Penelitian ini bertujuan untuk menganalisis pengaruh literasi keuangan terhadap kinerja dan keberlangsungan UMKM di Kota Denpasar. Pengumpulan data menggunakan kuesioner yang disebar langsung kepada objek penelitian. Populasi dalam penelitian adalah tiga sektor UMKM yang mendominasi di Kota Denpasar, yaitu sektor industri kerajinan, kuliner dan fashion sebanyak 330 UMKM. Sampel penelitian adalah sebanyak 100 UMKM dengan metode penentuan sampel, yaitu simple random sampling. Model persamaan struktural berbasis partial least square digunakan untuk menganalisis data. Hasil penelitian menunjukkan bahwa terdapat pengaruh yang signifikan antara literasi keuangan terhadap kinerja dan keberlangsungan UMKM di Kota Denpasar. Implikasi dari hasil penelitian ini adalah bahwa dengan pemahaman literasi keuangan yang baik diharapkan para pelaku UMKM akan mampu membuat keputusan keuangan dan manajemen yang tepat untuk peningkatan kinerja dan keberlanjutan usaha.
\end{abstract}

Kata Kunci: literasi keuangan, kinerja, keberlangsungan

\section{PENDAhULUAN}

Indonesia adalah salah satu negara dengan pertumbuhan ekonomi terbesar diantara negaranegara anggota G-20 dengan pertumbuhan ekonomi tahun 2018 sebesar 5,17 persen. Angka ini membawa Indonesia pada peringkat 4 (empat) di bawah Turki namun berada diatas negara-negara maju seperti: Amerika Serikat, Australia dan Korea Selatan. Arah Pertumbuhan ekonomi suatu 
negara dipengaruhi oleh berbagai sektor. Salah satu sektor yang mempengaruhi pertumbuhan ekonomi berbagai negara, termasuk Indonesia adalah sektor Usaha Mikro Kecil Menengah yang biasa disebut UMKM.

UMKM merupakan sumber mata pencaharian bagi orang banyak dan mampu menyediakan lapangan pekerjaan bagi mereka yang berpendidikan dan berketerampilan rendah serta mampu mengurangi kemiskinan (Agyapong, 2010). Sampai saat ini pun, UMKM dianggap sebagai cara yang efektif dalam menaikkan tingkat perekonomian Indonesia. Jumlah UMKM di Indonesia hingga saat ini mencapai 57 Juta UMKM, terbagi atas usaha mikro, kecil dan menengah. UMKM menyumbang sekitar 53 persen dari total Produk Bruto Indonesia dan kontribusi ekspor sebesar 20,52\%. UMKM juga menyerap tenaga kerja yang tidak sedikit, usaha mikro menyerap tenaga kerja sekitar 77 juta lebih tenaga kerja, usaha kecil sekitar 10 juta tenaga kerja dan usaha menengah hampir 5 juta tenaga kerja. Tentu ini merupakan perkembangan yang baik karena dengan demikian, UMKM dapat mengurangi tingkat pengangguran di Indonesia.

Perkembangan jumlah UMKM dapat dikatakan sangat pesat, namun saat ini UMKM masih tetap berada di zona usaha kecil dan terbilang sulit untuk dapat menjadi usaha besar. Secara umum, UMKM sering mengadapi masalah konvensional yang tidak terselesaikan secara tuntas (closed loop problems), seperti masalah kapasitas SDM, kepemilikan, pembiayaan, pemasaran dan berbagai masalah lain yang berkaitan dengan pengelolaan usaha, sehingga UMKM sulit bersaing dengan perusahaan-perusahaan besar (Abor \& Quartey, 2010). UMKM merupakan industri kreatif yang cenderung memiliki orientasi jangka pendek dalam pengambilan keputusan bisnisnya. Hal ini terlihat dari tidak adanya konsep inovasi yang berkelanjutan dan aktivitas inti bisnis yang tidak konsisten. Pada akhirnya kinerja jangka panjang UMKM yang bergerak pada industri kreatif cenderung stagnan dan tidak terarah dengan baik (Manurung \& Barlian, 2012). Demi meningkatkan kinerja dan keberlangsungan UMKM untuk jangka panjang, diperlukan pembentukan upaya-upaya strategis, seperti: memperkaya pengetahuan pelaku UMKM tentang pengelolaan keuangan dan akuntabilitas. Hal ini perlu dilakukan agar UMKM bisa mempertanggungjawabkan keuangannya dengan lebih baik dan teratur layaknya perusahaan besar. Selama ini, banyak pelaku UMKM yang kurang memperhatikan pengelolaan keuangan usahanya dengan menggabungkan uang pribadi dan uang usahanya. Hal ini merupakan salah satu faktor yang membuat terhambatnya perkembangan UMKM.

Salah satu cara yang dapat dilakukan untuk memperkaya pengetahuan dalam mengelola keuangan adalah dengan menggunakan literasi keuangan. Literasi keuangan adalah pemahaman tentang uang dan produk keuangan yang dapat diterapkan oleh seseorang pada pilihan keuangan mereka untuk membuat keputusan berdasarkan informasi tentang bagaimana menangani keuangan mereka (Amisi, 2012). Memiliki keterampilan literasi keuangan memungkinkan individu untuk membuat keputusan berdasarkan informasi tentang uang mereka dan meminimalkan kemungkinan disesatkan dalam masalah keuangan (Garg \& Singh, 2018). Semakin tinggi tingkat pengetahuan keuangan maka pengelolaan terhadap usaha yang dimiliki juga akan membaik. Literasi keuangan mempengaruhi cara berpikir seseorang terhadap kondisi keuangan serta mempengaruhi pengambilan keputusan yang strategis dalam hal keuangan dan pengelolaan yang lebih baik bagi pemilik usaha (Anggraeni, 2016). Literasi keuangan menyebabkan individu lebih sering membuat laporan keuangan usaha mereka. Pengusaha yang lebih sering menghasilkan laporan keuangan yang lebih baik akan memiliki tingkat profitabilitas yang tinggi dari pembayaran pinjaman dan untuk kelangsungan usahanya akan lebih tinggi (Wise, 2013). 
Berdasarkan penjelasan latar belakang diatas, maka yang menjadi pertanyaan peneliti dalam penelitian ini adalah sebagai berikut: 1) Apakah literasi keuangan berpengaruh terhadap kinerja UMKM di Kota Denpasar. 2) Apakah literasi keuangan berpengaruh terhadap keberlangsungan UMKM di Kota Denpasar.

Berdasarkan uraian pada latar belakang permasalahan, maka penelitian memiliki tujuan sebagai berikut: 1) Menganalisis pengaruh literasi keuangan terhadap kinerja UMKM di Kota Denpasar. 2) Menganalisis pengaruh li terasi keuangan terhadap keberlangsungan UMKM di Kota Denpasar

\section{TINJAUAN PUSTAKA}

The Association of Chartered Certified Accountants (2014) merumuskan bahwa konsep literasi keuangan mencakup pengetahuan mengenai konsep keuangan, kemampuan memahami komunikasi mengenai konsep keuangan, kecakapan mengelola keuangan pribadi/perusahaan dan kemampuan melakukan keputusan keuangan dalam situasi tertentu.

Kinerja UMKM dianalisis menggunakan pendekatan yang didasarkan pada tiga asumsi berikut, yaitu: (1) Pengukuran kinerja UMKM kerap sulit diakukan secara kuantitatif, dikarenakan terbatasnya sumber daya (pemahaman keuangan dan tenaga kerja). (2) Pengukuran kinerja pada umumnya melihat indicator keuangan yang kompleks, sehingga hal ini tidak secara lengkap memperlihatkan kondisi actual yang terjadi di bisnis tersebut. (3) Pengukuran kinerja yang kerap dipakai relative hanya sesuai bila digunakan untuk perusahaan besar yang terstruktur dalam manajemen perusahaannya.

Keberlanjutan usaha (business sustainability) pada UMKM dilihat dari keberhasilan perusahaan dalam melakukan inovasi, pengelolaan karyawan dan pelanggan serta pengembalian terhadap modal awalnya.

\section{METODE}

Penelitian ini dilakukan pada UMKM Sektor industri kerajinan, kuliner dan fashion yang ada di Kota Denpasar. Jumlah yang tercatat di Dinas Koperasi dan UMKM untuk ketiga sektor tersebut adalah 330 UMKM., dengan rincian: sektor industri kerajinan 41 UMKM, sektor kuliner 34 UMKM dan sektor fashion 255 UMKM. Metode penentuan sampel yang digunakan dalam penelitian ini adalah simple random sampling. Simple random sampling adalah metode pengambilan sampel secara acak tanpa memperhatikan strata yang ada dalam populasi (Sugiyono, 2012). Pengumpulan data dilakukan melalui survei dengan menggunakan kuesioner. Pengumpulan data dilakukan melalui survei dengan menggunakan kuesioner skala likert 5 point. Metode analisis data. menggunakan model persamaan structural berbasis partial least square (PLS).

\section{HASIL DAN PEMBAHASAN \\ Pengujian Model Struktural (Inner Model)}

Model struktural dalam PLS dievaluasi dengan menggunakan $\mathrm{R}^{2}$ untuk variabel dependen dan nilai koefisien path untuk variabel independen yang kemudian dinilai signifikansi berdasarkan nilai $t$-statistic setiap path. Adapun model struktural penelitian ini dapat dilihat pada gambar berikut: 


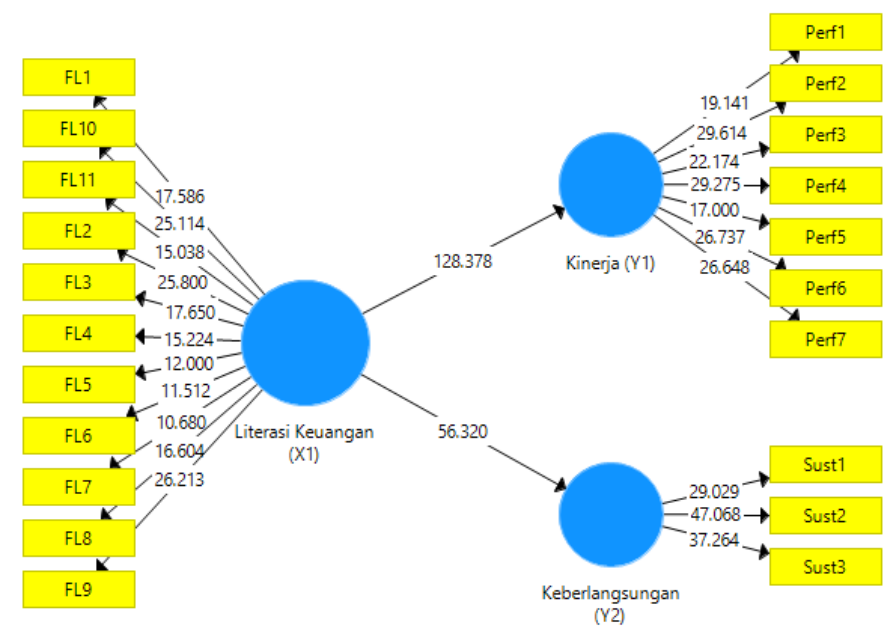

Gambar 1 Inner Model

Sumber : Hasil Olah Data Smart PLs 3, 2019

\section{Uji Path Coefficient}

Evaluasi path coefficient digunakan untuk menunjukkan seberapa kuat efek atau pengaruh variabel independen terhadap variabel dependen. Sedangkan coefficient determination $(R-$ Square) digunakan untuk mengukur seberapa banyak variabel endogen dipengaruhi oleh variabel lainnya. Chin menyebutkan hasil $\mathrm{R}^{2}$ sebesar $0,67 \mathrm{ke}$ atas untuk variabel laten endogen dalam model struktural mengindikasikan pengaruh variabel eksogen (yang mempengaruhi) terhadap variabel endogen (yang dipengaruhi) termasuk dalam kategori baik. Sedangkan, jika hasilnya sebesar 0,33 - 0,67 maka termasuk kategori sedang, dan jika hasilnya sebesar 0,19-0,33 maka termasuk dalam kategori lemah (Ghozali, 2014). Berikut tabel hasil path coefficient yang diperoleh dari output SmartPLS:

Tabel 1 Path Coefficients

\begin{tabular}{|c|c|c|c|c|}
\hline & $\begin{array}{c}\text { Original Sample } \\
\text { Estimate }\end{array}$ & $\begin{array}{c}\text { Mean of Sub } \\
\text { samples }\end{array}$ & $\begin{array}{c}\text { Standard } \\
\text { Deviation }\end{array}$ & T-Statistic \\
\hline $\mathrm{X} 1 \rightarrow$ Y1 & 0.960 & 0.961 & 0.007 & 128.378 \\
\hline $\mathrm{X} 1 \rightarrow$ Y2 & 0.902 & 0.905 & 0.016 & 56.320 \\
\hline
\end{tabular}

Sumber: Hasil Olah data SmartPls 3, 2019

Berdasarkan data tabel 1 di atas, dapat diketahui bahwa nilai path coefficient pengaruh literasi keuangan terhadap kinerja UMKM sebesar 128,378. Nilai path coefficient untuk pengaruh literasi keuangan terhadap keberlangsungan UMKM adalah sebesar 56,320. Hasil tersebut menunjukkan bahwa keseluruhan variabel dalam model ini memiliki nilai path coefficient dengan angka yang positif. Semakin besar nilai path coefficient pada satu variabel independen terhadap variabel dependen, maka semakin kuat pula pengaruh antar variabel independen terhadap variabel dependen tersebut.

\section{Uji Kebaikan Model (Goodness of Fit)}

Berdasarkan pengolahan data yang telah dilakukan dengan menggunakan program smartPLS 3.0, diperoleh nilai R-Square sebagai berikut: 
Tabel 2 Nilai $R$-Square

\begin{tabular}{|c|c|}
\hline Variabel & Nilai R-Square \\
\hline Kinerja (Y1) & 0.922 \\
\hline Keberlangsungan (Y2 & 0.814 \\
\hline
\end{tabular}

Sumber: Hasil Olah data SmartPls 3, 2019

Berdasarkan data tabel 2 dapat diketahui bahwa nilai $R$-Square untuk variabel kinerja adalah sebesar 0.922. Perolehan nilai tersebut menjelaskan bahwa presentase besarnya kinerja UMKM dapat dijelaskan oleh literasi keuangan sebesar 92,2 persen. Untuk nilai $R$-Square yang diperoleh variabel keberlangsungan adalah sebesar 0.814. Perolehan nilai tersebut menjelaskan bahwa presentase keberlangsungan UMKM dapat dijelaskan oleh literasi keuangan sebesar 81,4 persen. Penilaian goodness of fit diketahui dari nilai Q-Square. Nilai Q-Square memiliki arti yang sama dengan coefficient determinasi ( $R$-Square) pada analisis regresi, dimana semakin tinggi $Q-$ Square, maka model dapat dikatakan semakin baik atau semakin fit dengan data. Adapun hasil perhitungan nilai $Q$-Square adalah sebagai berikut:

$$
\begin{aligned}
Q \text {-Square } & =1-\left[\left(1-\mathrm{R}^{2} 1\right) \times\left(1-\mathrm{R}^{2} 2\right)\right] \\
& =1-[(1-0,922) \times(1-0,814)] \\
& =1-(0,078 \times 0,186) \\
& =1-0,014 \\
& =0,986
\end{aligned}
$$

Berdasarkan hasil perhitungan di atas, diperoleh nilai $Q$-Square sebesar 0,986. Hal ini menunjukkan besarnya keragaman dari data penelitian yang dijelaskan oleh model penelitian adalah sebesar 98,6 persen. Sedangkan sisanya sebesar 1,4 persen dijelaskan oleh faktor lain yang berada di luar model penelitian ini. Hasil tersebut menyatakan bahwa model penelitian ini telah memiliki goodness of fit yang baik.

\section{Pengujian Hipotesis}

Uji hipotesis pada penelitian ini dilakukan dengan melihat hasil nilai T-Statistic dan nilai $P$-Values. Hipotesis penelitian dapat dinyatakan diterima apabila nilai $P$-Values $<0,05 \mathrm{r}$ ini adalah hasil uji hipotesis yang diperoleh dalam penelitian ini melalui inner model:

\section{Tabel 3 T-Statistic dan P-Values}

\begin{tabular}{|c|c|c|c|c|}
\hline Hipotesis & Pengaruh & $\begin{array}{c}T- \\
\text { Statistic }\end{array}$ & $\begin{array}{c}P- \\
\text { Values }\end{array}$ & Hasil \\
\hline H1 & $\begin{array}{c}\text { Literasi Keuangan } \rightarrow \text { Kinerja } \\
\text { UMKM }\end{array}$ & 128.378 & 0.000 & Diterima \\
\hline H2 & $\begin{array}{c}\text { Literasi Keuangan } \rightarrow \\
\text { Keberlangsungan UMKM }\end{array}$ & 56.320 & 0.000 & Diterima \\
\hline
\end{tabular}

Sumber: Hasil Olah data SmartPls 3, 2019

Berdasarkan data tabel 3 di atas, dapat diketahui bahwa dari dua hipotesis yang diajukan dalam penelitian ini, semuanya dapat diterima karena masing-masing pengaruh yang ditunjukkan memiliki nilai $P$-Values $<0,05$. Sehingga dapat dinyatakan variabel independen (literasi keuangan) memiliki pengaruh yang signifikan terhadap variabel dependen (Kinerja dan Keberlangsungan UMKM).

Nilai t-statistic hipotesis pertama yaitu literasi keuangan terhadap kinerja adalah sebesar 128,378 dan nilai t-statistic untuk hipotesis kedua, yaitu pengaruh literasi keuangan terhadap 
keberlangsungan adalah sebesar 56,320. Hasil tersebut menunjukkan bahwa kedua hipotesis dapat diterima karena nilai t-statistic masing-masing variabel > 1,96 (t-tabel).

\section{Pembahasan Hasil Uji Hipotesis \\ Pengaruh Literasi Keuangan Terhadap Kinerja UMKM}

Hasil uji hipotesis menunjukkan nilai P-Values yang membentuk pengaruh literasi keuangan terhadap kinerja UMKM adalah sebesar 0,000 dan nilai T-statistic yang positif $(128,378)$. Hasil ini menunjukkan bahwa variabel literasi keuangan berpengaruh positif terhadap kinerja UMKM. Berarti, apabila tingkat literasi keuangan seorang pemilik maupun manajer sebuah UMKM semakin tinggi maka kinerja yang dapat dicapai oleh UMKM tersebut akan semakin meningkat. Keberhasilan atau kegagalan usaha kecil sangat dipengaruhi oleh keterampilan dan kemampuan pelaku usaha dan di dalam suatu proses kewirausahaan diperlukan tiga kategori dasar modal yang berkontribusi pada usaha yang sukses, yaitu modal manusia, modal sosial dan modal keuangan. Salah satu kategori yang diharapkan berkontribusi adalah modal keuangan, sehingga setiap UMKM perlu memperhatikan pengetahuan sumber daya manusia yang bersangkutan terkait dengan pengelolaan keuangan. Hasil ini sejalan dengan penelitian (Ratnawati, 2016) dan (Aribawa, 2016) yang menyatakan bahwa literasi keuangan mampu menunjukkan pengaruh positif terhadap kinerja usaha. Literasi keuangan membantu usaha kecil untuk memperoleh pengetahuan, keterampilan dan kemampuan untuk menyusun strategi keuangan untuk membuat keputusan dan pilihan layanan keuangan. Literasi keuangan membantu pemilik usaha untuk memperoleh pengetahuan keuangan dan ketrampilan yang diperlukan bagi mereka untuk membuat perencanaan bisnis, memulai rencana keuangan dan membuat keputusan investasi strategis.

Perusahaan yang memiliki literasi keuangan yang baik akan mampu secara strategis mengidentifikasi dan merespon perubahan iklim bisnis, ekonomi dan keuangan sehingga keputusan yang diambil akan menciptakan solusi inovatif dan terarah dengan baik untuk peningkatan kinerja dan keberlanjutan usaha (Aribawa, 2016). Hasil penelitian ini mendukung hasil penelitian dari (Njoroge C.W \& Gathungu, 2013) dan (Otieno et al., 2013). Literasi keuangan membangun kepercayaan diri seseorang, membuat pelaku usaha lebih tahu dan terdidik sehingga mampu mengambil tanggung jawab untuk masalah keuangan dan mampu memainkan peran lebih aktif di pasar untuk layanan keuangan. Pelaku usaha kecil yang tidak berpendidikan dan tidak memiliki pengetahuan keuangan akan terdorong menuju alternatif pembiayaan ilegal dan mahal. Proses literasi keuangan bisa menguntungkan bank karena memiliki keunggulan sebagai pusat interaksi dengan pencari modal dalam hal ini pelaku usaha. Namun, hasil penelitian berbeda dengan hasil penelitian dari (Eresia-Eke \& Raath, 2013), (Kusumadewi, 2017) dan (Anggraeni, 2016) yang menyatakan bahwa tidak terdapat hubungan antara literasi keuangan dan pertumbuhan usaha serta kinerja dari UKM.

\section{Pengaruh Literasi Keuangan Terhadap Keberlangsungan UMKM}

Hasil uji hipotesis menunjukkan nilai P-Values yang membentuk pengaruh literasi keuangan terhadap kinerja UMKM adalah sebesar 0,000 dan nilai T-statistic yang positif $(56,320)$. Hasil ini menunjukkan bahwa variabel literasi keuangan berpengaruh positif terhadap keberlangsungan UMKM. Hasil penelitian ini mendukung penelitian sebelumnya (Drexler et al., 2014) yang menyatakan bahwa literasi keuangan akan mendukung dalam pengambilan keputusan keuangan yang sifatnya kompleks dan literasi keuangan tersebut menjadi salah satu pendukung dalam menjaga keberlanjutan usahanya. Hasil penelitian ini juga mendukung 
penelitian yang dilakukan Aribawa (2016) dan (Widayanti et al., 2017). Menurut (Krishna et al., 2007) menjelaskan bahwa literasi keuangan menjadi unsur yang sangat penting, beberapa kasus bagi individu yang memiliki dasar literasi keuangan akan dapat melalui masa-masa keuangan yang sulit, kesulitan keuangan juga dapat muncul jika terjadi kesalahan dalam pengelolaan keuangan, seperti: kesalahan penggunaan kredit, tidak adanya perencanaan keuangan sehingga kemampuan literasi keuangan akan membantu individu dalam mengatur perencanaan keuangan pribadi, yang nantinya individu tersebut dapat memaksimalkan nilai waktu uang dalam investasinya dan keuntungan yang diperoleh juga semakin meningkatkan taraf kehidupannya.

Hasil ini mengonfirmasi hasil penelitian sebelumnya yang dilakukan oleh (Dahmen \& Rodríguez, 2014), (Fatoki, 2014), (Wise, 2013), serta (Adomako et al., 2016). Secara umum, hasil penelitian mereka menyatakan bahwa bila pengusaha di sektor UMKM (dalam penelitian ini UMKM sektor industri kerajinan, kuliner dan fashion di Kota Denpasar) memiliki kemampuan literasi keuangan yang memadai, maka keputusan bisnis dan keuangan yang diciptakan akan menuju ke arah pengembangan yang membaik dari waktu ke waktu, meningkatkan kemampuan usaha untuk bertahan di tengah krisis dan pada akhirnya akan membuat bisnis tersebut memiliki keberlanjutan usaha jangka panjang.

Pemahaman pelaku UMKM di Kota Denpasar, khususnya sektor kerajinan, kuliner dan fashion terkait dengan literasi keuangan masih kurang, ditunjukkan masih sebagian kecil yang melakukan pencatatan setiap transaksi keuangan, pengetahuan tentang kredit juga belum maksimal, sedikit yang mengajukan permodalan ke bank dan belum melakukan perencanaan keuangan dengan benar terlihat masih bercampurnya keuangan usaha dengan keuangan rumah tangga. Kesulitan yang dialami pelaku UMKM khususnya dalam melakukan pengelolaan keuangan disebabkan kurangnya pemahaman tentang literasi keuangan dan ini berdampak pada pendapatan dan kesejahteraan yang kurang maksimal, kondisi yang ditemui pada UMKM Kota Denpasar ini sesuai dengan penelitian.

Karakteristik UMKM di Kota Denpasar cukup unik dalam menghadapi perubahan lingkungan bisnis dan stakeholder. UMKM - UMKM tersebut lebih menekankan pada kerjasama antar pelaku usaha (kooperatif) bukan persaingan sehingga upaya ini yang benar- benar dijaga dalam mempertahankan keberlangsungan usaha. Adanya knowledge sharing dan kerjasama intra UMKM dipakai sebagai upaya meningkatkan kemampuan dan masih lekat keinginan saling melengkapi serta membantu kesulitan yang dihadapi pelaku usaha. Gerakan komunitas para pengusaha muda yang mulai bermunculan saat ini adalah bukti bahwa sektor UMKM berupaya untuk enabling smallness untuk memperoleh keuntungan dari kolaborasi, knowledge sharing dan channel sharing yang terjadi di komunitas tersebut. Komunitas menjadi elemen penting sebagai perwujudan perkembangan, penentu arah kebijakan dan menjaga lingkungan bisnis agar tetap kuat dan mampu bersaing di pasar global.

\section{KESIMPULAN}

Aspek keuangan merupakan salah satu aspek yang penting dalam aktivitas bisnis sehingga diharapkan para pelaku usaha memiliki pemahaman yang baik tentang pengelolaan keuangan. Pengelolaan keuangan akan memberikan dampak yang beragam tergantung dari pemahaman para pelaku usaha. Tentu saja para pelaku usaha tersebut mengharapkan yang terbaik bagi usahanya, baik kinerja maupun keberlangsungan usahanya. Penelitian ini bertujuan untuk menganalisis pengaruh literasi keuangan terhadap kinerja dan keberlangsungan UMKM di Kota Denpasar. Penelitian ini menggunakan 100 orang pelaku UMKM sebagai responden dan berasal dari tiga 
sektor utama di Denpasar, yaitu sektor industri kerajinan, kuliner dan fashion. Hasil penelitian menunjukkan bahwa literasi keuangan berpengaruh signifikan terhadap kinerja dan keberlangsungan UMKM di Kota Denpasar.

\section{DAFTAR PUSTAKA}

Abor, J., \& Quartey, P. (2010). Issues in SME development in Ghana and South Africa. International Research Journal of Finance and Economics, 39(May 2010), 218-228.

Adomako, S., Danso, A., \& Ofori Damoah, J. (2016). The moderating influence of financial literacy on the relationship between access to finance and firm growth in Ghana. Venture Capital, 18(1), 43-61. https://doi.org/10.1080/13691066.2015.1079952

Agyapong, D. (2010). Micro, Small and Medium Enterprises' Activities, Income Level and Poverty Reduction in Ghana - A Synthesis of Related Literature. International Journal of Business and Management, 5(12). https://doi.org/10.5539/ijbm.v5n12p196

Amisi, S. (2012). The Effect of Financial Literacy on Investment Decision Making by Pension Fund Managers in Kenya. July, 1-74.

Anggraeni, B. D. (2016). Pengaruh Tingkat Literasi Keuangan Pemilik Usaha Terhadap Pengeloaan Keuangan. Studi Kasus : Umkm Depok. Jurnal Vokasi Indonesia, 4(1). https://doi.org/10.7454/jvi.v4i1.50

Aribawa, Dwitya. 2016. Pengaruh Literasi Keuangan Terhadap Kinerja Dan Keberlangsungan UMKM di Jawa Tengah. Jurnal Siasat Bisnis. 20(1). 1-13

Dahmen, P., \& Rodríguez, E. (2014). Financial Literacy and the Success of Small Businesses: An Observation from a Small Business Development Center. Numeracy, 7(1). https://doi.org/10.5038/1936-4660.7.1.3

Drexler, A., Fischer, G., \& Schoar, A. (2014). Keeping it simple: Financial literacy and rules of thumb. American Economic Journal: Applied Economics, 6(2), 1-31. https://doi.org/10.1257/app.6.2.1

Eresia-Eke, C. E., \& Raath, C. (2013). SMME Owners' financial literacy and business growth. Mediterranean Journal of Social Sciences, 4(13), 397-406. https://doi.org/10.5901/mjss.2013.v4n13p397

Fatoki, O. (2014). The Financial Literacy of Micro Entrepreneurs in South Africa. Journal of Social Sciences, 40(2), 151-158. https://doi.org/10.1080/09718923.2014.11893311

Garg, N., \& Singh, S. (2018). Financial literacy among youth. International Journal of Social Economics, 45(1), 173-186. https://doi.org/10.1108/IJSE-11-2016-0303

Ghozali, I. (2014). Structural Equation Modeling : Metode Alternatif dengan Partial Least Square (PLS) (4th ed.). Badan Penerbit Universitas Diponegoro.

Krishna, A. S. S., Sari, M., \& Rofaida, R. (2007). Analisis Tingkat Literasi Keuangan Di Kalangan Mahasiswa dan Faktor-Faktor yang Mempengaruhinya. Survey Pada Mahasiswa Universitas Pendidikan Indonesia (Financial Literacy Level Analysis Among Students and Its Affecting Factors. Survey on UPI). Academia.Edu, November, $\underline{1-6 .}$ 
Kusumadewi, N. R. (2017). Pengaruh Locus of Control Dan Financial Literacy Terhadap Kinerja Ukm Pada Pelaku Ukm Desa Rawa. Prosiding Seminar Nasional Dan Call for Papers, 5(November), 915-924.

Manurung, E. M., \& Barlian, I. (2012). From Small to Significant: Innovation Process in SmallMedium Creative Businesses. International Journal of Innovation, Management and Technology, 3(6), 788. https://doi.org/10.7763/IJIMT.2012.V3.339

Njoroge C.W \& Gathungu, J. (2013). The effect of entrepreneurial education and training on development of small and medium size enterprises in Githunguri District Kenya International. Journal of Education and Research, 1(8), 1-22.

Otieno, S., Lumumba, M., Nyabwanga, Ojera, P., \& Alphonce, J. O. (2013). Effect of provision of micro-finance on the performance of micro-enterprises: A study of youth microenterprises under Kenya Rural Enterprise Program (K-REP), Kisii County, Kenya. African Journal of Business Management, 5(20), 8290-8300. https://doi.org/10.5897/ajbm11.1419

Ratnawati. (2016). Tingkat Pendididkan, Pengetahuan Literasi Keuangan, Sustainability Usaha Sebagai Upaya Meningkatkan Kinerja Manajemen UKM. Ilmiah - Vidya, 24(2), 24$\underline{32 .}$

Sugiyono. (2012). Metode Penelitian Bisnis. Alfabeta.

Widayanti, R., Damayanti, R., \& Marwanti, F. (2017). Pengaruh Financial Literacy Terhadap Keberlangsungan Usaha (Business Sustainability) Pada Umkm Desa Jatisari. Jurnal Ilmiah Manajemen \& Bisnis, 18(2), 153. https://doi.org/10.30596/jimb.v18i2.1399

Wise, S. (2013). The Impact of Financial Literacy on New Venture Survival. International $\begin{array}{llll}\text { Journal of Business and } & \text { Management, } & \text { 30-39. }\end{array}$ https://doi.org/10.5539/ijbm.v8n23p30 